\title{
Virulence factors and phylotyping of Escherichia coli isolated from non-diarrheic and diarrheic water buffalo calves
}

\section{Fernanda Morcatti Coura ${ }^{1,2}$ Soraia de Araújo Diniz ${ }^{1}$ Marcos Xavier Silva ${ }^{1}$ Cairo Henrique Sousa de Oliveira ${ }^{3}$ (D) Jamili Maria Suhet Mussi ${ }^{1}$ Camila Stefanie Fonseca de Oliveira ${ }^{1}$ Andrey Pereira Lage ${ }^{1}$ Marcos Bryan Heinemann ${ }^{*}$ iD}

\footnotetext{
${ }^{1}$ Departamento de Medicina Veterinária Preventiva, Universidade Federal de Minas Gerais (UFMG), Belo Horizonte, MG, Brasil. ${ }^{2}$ Departamento de Ciências Agrárias, Instituto Federal de Minas Gerais, Bambuí, MG, Brasil.

${ }^{3}$ Programa de Pós-Graduação em Ciência Animal (PPGCA), Universidade Federal de Goiás (UFG), Goiânia, GO, Brasil e Ministério da Agricultura, Pecuária e Abastecimento (MAPA), Brasil.

${ }^{4}$ Departamento de Medicina Veterinária Preventiva, Faculdade de Medicina Veterinária e Saúde Animal, Universidade de São Paulo (USP), 05508-270, São Paulo, SP, Brasil. E-mail: marcosbryan@usp.br. "Corresponding author.
}

\begin{abstract}
This study aimed to determine the virulence factors, phylogenetic groups, and the relationships between pathovars and phylogenetic groups of E. coli strains isolated from feces of buffalo calves. A total of 217 E. coli strains were obtained from feces after culture and were screened by PCR for detection of virulence factors EAST-1, enterohemolysin, Saa, CNF2, F41, F5, STa, intimin, Stx1 and Stx2. One hundred and thirty-four isolates were positive for one or more virulence factors: eighty-four from diarrheic animals, and fifty from nondiarrheic calves. The pathovars of E. coli identified in diarrheic feces were ETEC $\left(F 5^{+}\right)(2 / 84), N T E C(16 / 84)$, STEC (20/84), EPEC (3/84), EHEC (3/84), and EAEC (EAST-1 $\left.{ }^{+}\right)$(33/84). Pathovars identified in non-diarrheic animals were NTEC (21/50), STEC (17/50), EHEC (1/50) and EAEC (7/50). E. coli strains positive for EAST-1 $(P=0.008)$ and phylogroup $C(P=0.05)$ were associated with the presence of diarrhea. Phylogenetic analysis showed that 58.95\% of the isolates belonged to phylogroup B1, followed by E (9.70\%), B2 (5.90\%), C (5.90\%), D $(5.22 \%), A(2.24 \%)$, and $F(1.50 \%)$. Phylogroup B1 predominated in pathogenic E. coli isolated from water buffalo, and phylogroup $C$ constituted an enteropathogenic E. coli for water buffalo calves.
\end{abstract}

Key words: buffalo calves, diarrhea, Escherichia coli, pathovars, phylogenetic group.

Caracterização dos fatores de virulência e filogrupos de Escherichia coli isoladas de bezerros bubalinos sem diarreia e diarreicos

RESUMO: O objetivo foi determinar os fatores de virulência, os grupos filogenéticos e as possíveis relações entre os patovares e os grupos filogenéticos identificados de cepas de Escherichia coli isoladas de fezes de bezerros bubalinos. Um total de 217 amostras de E. coli foram identificadas a partir de cultura das fezes e submetidas a reação em cadeia da polimerase (PCR) para detecção dos fatores de virulência EAST-1, enterohemolisina, Saa, CNF2, F41, F5, STa, intimina, Stx1 e Stx2. Foram identificadas 134 cepas positivas para um ou mais fatores de virulência: 84isoladas de bezerros bubalinos diarreicos e 50 de bezerros bubalinos saudáveis. Os patovares de E. coli obtidos de fezes diarreicas foram ETEC (F5 ) (2/84), NTEC (16/84), STEC (20/84), EPEC (3/84), EHEC (3/84), e EAEC (EAST-1 $\left.{ }^{+}\right)(33 / 84)$. Os patovares isolados de fezes não diarreicas foram NTEC (21/50), STEC (17/50), EHEC (1/50) e EAEC (7/50). Cepas de E. coli positivas para EAST-1 $(P=0,008)$ e filogrupo $C(P=0,05)$ foram associadas com a presença de diarreia. A análise de filogrupos revelou que 58,95\% dos isolados pertencem ao filogrupo B1, seguido por E (9,70\%), B2 (5,90\%), C (5,90\%), D (5,22\%), A (2,24\%) e F (1,50\%). O filogrupo B1 predomina em cepas de E. coli patogênicas isoladas de bezerros búfalos e o filogrupo C constitui um filogrupo de E. coli patogênica entérica para bezerros. Palavras-chave: bezerros bubalinos; dirreia, Escherichia coli;,grupo filogenético, patovares.

\section{INTRODUCTION}

Diarrhea is an important health concern in young animals, and frequently $E$. coli pathovars such as enterotoxigenic E. coli (ETEC), Shiga-toxin producing E. coli (STEC), enterohemorrhagic E. coli (EHEC), and entero-pathogenic E. coli (EPEC), are associated with its etiology (CROXEN \& FINLAY 2010). Water buffalo calves are susceptible to all
E. coli pathovars that cause diarrhea in bovine calves, including necrotoxigenic E. coli (NTEC) (BORRIELLO et al., 2012).

There are a few studies involving $E$. coli pathovar infections in buffalo calves worldwide (OLIVEIRA et al., 2007; BORRIELLO et al., 2012; MAHANTI et al., 2013; BERALDO et al., 2014). Most previous studies focused on STEC infections, and phylogenetic classification was not performed. 
Moreover, a heat stable toxin called EAST-1, primarily detected in strains of entero-aggregative E. coli (EAEC) strains, can also occur in other pathovars such as ETEC, EPEC, and EHEC, and has been identified in strains of $E$. coli isolated from cattle and humans with diarrhea (NAGY \& FEKETE, 2005; VEILLEUX \& DUBREUIL, 2006); although, its ability to cause diarrhea in calves is less known (KOLENDA et al., 2015).

The study of infections with enteric $E$. coli pathovars in buffalo calves is necessary for the development of effective prophylactic and therapeutic protocols for the control of pathogenic $E$. coli infections on buffalo farms (BORRIELLO et al., 2012). In addition, food-producing animals represent an important source of EHEC in the food chain (MARTIN \& BEUTIN 2011). EHEC, O157:H7 in particular, causes hemorrhagic colitis and hemolytic uremic syndrome in humans, and contaminated foods of animal origin are considered the main form of EHEC transmission to humans (DOYLE, 1991). Furthermore, contamination with EHEC and STEC in dairy products from buffalo cows represents a potential risk to public health; hence, the frequency of these pathovars in buffalos needs to be determined.

$E$. coli strains can be classified into one of seven phylogroups: A, B1, B2, C, D, E, and F (CLERMONT et al., 2013). The MLST is the best technique for typing $E$. coli, but the sequence type (ST) provided in such analysis does not directly allow for classification into phylogroups, and it is necessary to determine the correspondence between ST and phylogroups, with the latter performed by means of the "Clermont method". Improved understanding of $E$. coli phylogeny revealed that strains belonging to the different phylogroups are not dispersed randomly, and are associated with the source of isolation. Since its introduction in 2000, phylogenetic typing using polymerase chain reaction (PCR) became widely used due to its simplicity and rapidity. The method was improved in 2013, and, by means of quadruplex PCR, can identify the seven defined phylogroups (CLERMONT et al., 2000; CLERMONT et al., 2013; CLERMONT et al.,2015). Phylogenetic typing using PCR has $80-95 \%$ concordance with MLST analysis, showing that such testing can be used to study the genetic diversity of strains of $E$. coli (GORDON et al., 2008; CLERMONT et al., 2013).

Because of the lack of information regarding pathogenic $E$. coli in water buffalos, this study sought to determine the (i) virulence factors involved, (ii) phylogenetic groups involved, and (iii) relationships between pathovars and phylogenetic groups of $E$. coli strains isolated from feces of buffalo calves.

\section{MATERIALS AND METHODS}

Animals

Fecal specimens were collected from water buffalo calves on five farms located in Minas Gerais, two from Carmo da Mata, and three from Oliveira counties. All farms bred only Mediterranean and/or Murrah buffalos for milk production. Fecal samples were collected in 2013 from 152 water buffalo calves up to 90 days of age.

Animals were selected randomly, and each buffalo calf was sampled once during a visit to each farm. Feces were classified as diarrheic if they had a watery to paste-like consistency, and as normal if they had a firm consistency, and the perineum and tail of the animals were clean. At the time of sampling, 107 animals were considered diarrheic and 45 nondiarrheic. Samples were collected directly from buffalo calf recta in plastic bags and stored at $4{ }^{\circ} \mathrm{C}$ until bacteriological examination.

\section{Bacteriological examination}

Bacterial examination was performed according to COURA et al. (2015a). E. coli strains were stored at room temperature $\left(25^{\circ} \mathrm{C}\right)$ in nutrient agar (NA) for a maximum period of two months before molecular analysis.

\section{DNA extraction and PCR}

E. coli isolates in NA were plated onto MacConkey agar and incubated for $18-24 \mathrm{~h}$ at $37{ }^{\circ} \mathrm{C}$. Next, bacterial cells were re-suspended in $100 \mu \mathrm{L}$ of TE (10 mM Tris-HCl; EDTA $1 \mathrm{mM}, \mathrm{pH} 8.0)$ in 1.5 $\mathrm{mL}$ microtubes, and DNA was extracted according to Pitcher et al.(PITCHER at al., 1989).

The PCR was performed to determine the presence of the following virulence factors: EAST1 (YAMAMOTO \& NAKAZAWA, 1997), EHEC hemolysin (SCHMIDT et al. 1995), Saa(JENKINS et al., 2003), CNF2 (BLANCO et al., 1996), F41, F5, $\mathrm{STa}$, eae, Stx1, and Stx2 (multiplex PCR) (FRANCK et al., 1998). E. coli reference strains used as positive controls were: B41 (O101: H-: F41+, F5+, STa+) and EDL 933 (O157: H7; Stx1+, Stx2+, eae+, hlyA $^{+}$, EAEC O42 (EAST-1+), S5 (CNF2+) and STECLBA05 $(\mathrm{Saa}+)$. Ultra-pure water was used for negative controls.

The E. coli strains were classified into pathovars according to the virulence factors identified by PCR. E. coli strains positive for STa and/or F5 
were classified as ETEC; if positive for Stx2 and/ or Stx1,they were considered STEC; EHEC strains were identified as positive for Stx and intimin; strains positive for intimin only were classified as EPEC; strains positive for CNF2 were classified as NTEC; Strains positive for EAST-1 only were classified as EAEC pathovars. Atypical combinations of virulence factors of $E$. coli isolates, which did not permit classification as pathovars were classified as "Others".

\section{Phylotyping}

Phylotyping of E. coli strains was performed as reported previously (COURA et al., 2015b), and according to CLERMONT et al. (2013), and used in the present study for analysis of associations between pathovars, presence of diarrhea, and $E$. coli phylogroups. If a phylogenetic group could not be identified, such $E$. coli isolates were screened for the presence of the uidA gene to confirm the detection of E. coli (MCDANIELS et al., 1996), as suggested by CLERMONT et al. (2013).

\section{Statistical analysis}

All data analyses were carried out using Stata Statistical Software (STATACORP, 2011). Associations involving fecal consistency, pathovars, and phylogroups, were studied using the Chi-square test or Fisher's exact test. Results were expressed as $\mathrm{P}$ values. Results were considered statistically significant at $\mathrm{P} \leq 0.05$. Correspondence analysis (CA) (GREENACRE \& BLASIUS,2006) was used to study pathovar categories and phylogroups. In CA, relationships between categories were represented in two-dimensional graphs, with the value of the third dimension shown in parenthesis. The relatedness between pathovars and phylogroups was demonstrated by evaluating which variables plotted closely together (HAIR,2009).

\section{RESULTS}

In total, 217 E. coli strains were analyzed by PCR screening for virulence factors. One hundred and thirty-four isolates $(61.75 \%)$ were positive for one or more virulence factors: $84(62.68 \%)$ from diarrheic feces, and $50(37.32 \%)$ from normal feces. Figure 1 illustrates the virulence factors and pathovars of $E$. coli strains identified in diarrheic and fecal samples. The identification of $E$. coli strains positive for EAST-1 (EAEC) was associated with the presence of diarrhea $(\mathrm{P}=0.008)$.

Phylogenetic analysis of the 134 E. coli strains isolated from buffalo calves showed that
$58.95 \%$ of the isolates belonged to phylogroup B1, followed by $\mathrm{E}(9.70 \%), \mathrm{B} 2(5.90 \%), \mathrm{C}(5.90 \%)$, D $(5.22 \%), A(2.24 \%)$, and F (1.50\%). Fourteen strains were assigned as "unknown" because they were positive for the four genes $\operatorname{arpA} / \mathrm{chuA} /$ yjaA/TspE4.C2, and were screened for the uidA gene, confirming the detection of E. coli (Table 1). According to CLERMONT et al. (2013), MLST should be performed to classify such strains. All seven phylogenetic groups were detected in E. coli isolated from diarrheic feces; although, phylogenetic groups $\mathrm{A}$ and $\mathrm{F}$ were identified at low frequency. Phylogroups $\mathrm{A}$ and $\mathrm{C}$ were not found in isolates from normal feces. Phylogroup $\mathrm{C}$ was associated with the presence of diarrhea $(\mathrm{P}=0.05)$.

The distribution of 134 strains in relation to pathovars and phylogenetic groups from diarrheic and normal feces showed that ETEC pathovars included only phylogroups $\mathrm{E}(1 / 2)$ and $\mathrm{F}(1 / 2)$; NTEC phylogroups B1 (23/37), B2 (6/37), D (3/37), and E (4/37); STEC phylogroups B1 (14/37), B2 (2/37), C (2/37), D (3/37), E (5/37), and F (1/37); all three EPEC strains B1; EHEC phylogroup B1 (3/4); EAEC included phylogroups A (3/40), B1 (30/40), C (4/40), D (1/40), and E (2/40). Strains of "unknown "phylogenetic grouping were identified in NTEC (1/37), STEC (10/37), and EHEC (1/4).

$\mathrm{CA}$ was performed using the pathovar and phylogenetic grouping, and a representation of the two dimensions and the value of the third are shown in figure 2. This bidimensional representation explains $94.55 \%$ of the total variation, with $47.68 \%$ explained by the 1 st dimension, $26.63 \%$ by the 2 nd dimension, and $20.63 \%$ by the 3 rd. The NTEC was close to phylogroup B2 and, to a lesser extent, to phylogroup D. EPEC and EAEC (EAST-1 positive strains) was proximal to phylogroup B1, and EHEC was relatively coincident with phylogroup A. The ETEC (F5) was close to phylogroup F.

\section{DISCUSSION}

Diarrheagenic E. coli is an important cause of diarrhea in water buffalos (FAGIOLO et al. 2005; BORRIELO et al., 2012). Only two ETEC $\left(\mathrm{F}^{+}\right)$strains were isolated in our study. Previous studies in water buffalos reported infrequent occurrences of ETEC fimbria and thermostable enterotoxin (GALIERO et al., 2005; BORRIELLO et al., 2012) among $E$. coli isolates from those animals. Collectively, these results suggested that ETEC is not an important pathogen for water buffalo calves, whereas it is for bovine calves. 


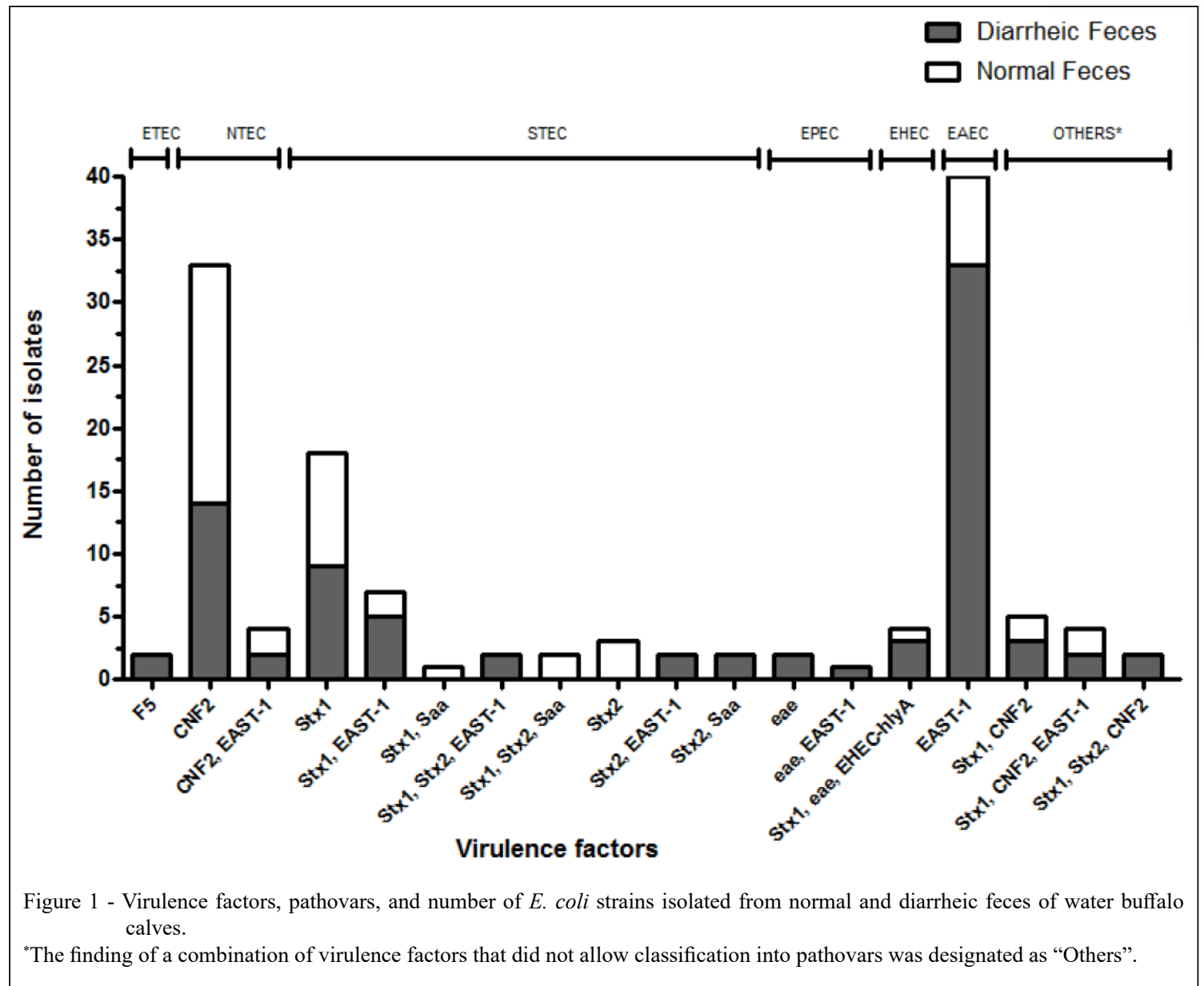

In our study, EAST-1was detected at a high frequency and was associated with the presence of diarrhea, indicating that $E$. coli strains harboring the gene for this toxin might play a role in the pathogenesis of diarrhea in water buffalo calves. The EAST-1 is a heat stable toxin, primarily detected in the strains of entero-aggregative $E$. coli (EAEC), and can also occur in other pathovars such as ETEC, EPEC, and EHEC (NAGY \& FEKETE 2005). The EAST-1 has been identified in the strains of $E$. coli isolated from swine and cattle suffering from diarrhea and/or edema disease, and in humans with diarrhea (VEILLEUX \& DUBREUIL, 2006), but its role in the pathogenesis of diarrhea in calves is unclear (KOLENDA et al., 2015). This is the first study evaluating the importance of this toxin and diarrhea in water buffalo, and our results demonstrated that EAST-1 should be considered as an additional determinant in the pathogenesis of diarrhea in water buffalos.
The low frequency of EPEC in our study is in accordance with other studies on buffalos in Brazil (BERALDO et al., 2014), India (MAHANTI et al., 2013), and central Vietnam (VU-KHAC \& CORNICK 2008). The EPEC was also detected at a low frequency in isolates of $E$. coli from bovine fecal samples in Brazil (ANDRADE et al., 2012; COURA et al., 2015a), in Turkey (OK et al., 2009), and in Vietnam (NGUYEN et al.,2011). Although, these studies differ in terms of geographical regions and methodologies, results indicated that the occurrence of EPEC is low.

The overall frequency of STEC was $26.12 \%$. Other studies reported similar results (OLIVEIRA et al., 2007; BERALDO et al., 2014). GALIERO et al. (2005) showed that $6.5 \%$ of E. coli strains isolated from buffalo calves with enteric and systemic diseases produced Shiga toxin. BORRIELO et al. (2012) investigated the presence of pathogenic $E$. coli in water buffalo calves (younger than 4 weeks 
Table 1 - Absolute frequency of phylogenetic groups of $E$. coli isolated form diarrheic and normal water buffalo calf feces.

\begin{tabular}{lrrrrrrrc}
\hline $\begin{array}{l}\text { Fecal } \\
\text { characteristics }\end{array}$ & \multicolumn{1}{c}{-1} & \multicolumn{1}{c}{----------Phylogenetic group--------------- } \\
\hline & A & B1 & B2 & C & D & E & F & Unknown \\
\hline Diarrheic & 3 & 50 & 2 & 8 & 4 & 6 & 1 & 10 \\
Normal & 0 & 29 & 6 & 0 & 3 & 7 & 1 & 4 \\
Total & 3 & 79 & 8 & 8 & 7 & 13 & 2 & 14 \\
\hline
\end{tabular}

of age) with diarrhea, and STEC was detected in $6.8 \%$ of the strains. This variation in frequency may occur due to the number of animals studied, the age of animals, and the different regions involved, but collectively, results demonstrated that STEC is an important pathogen for buffalo calves. Furthermore, ruminants are an important reservoir of the human pathogens STEC/EHEC, and the presence of these pathogens in water buffalo feces may represent a potential risk to human health, especially through consumption of buffalo raw milk.

The presence of the gene for Saa detected in STEC isolates from water buffalos is in agreement with a report by OLIVEIRA et al. (2007). PATON et al. (2001) first described the gene for Saa in locus of enterocyte effacement-negative STEC, and Jenkins et al. (JENKINS et al., 2003) suggested that Saa might have a role in attachment to the bovine gut. Enterohemolysin (ehxA) was not detected in association with Saa, but instead was reported in eaeand $s t x$-positive strains. Similar results were presented by BORRIELO et al. (2012) and BERALDO et al.(2014). In contrast, VU-KHAC and CORNICK (2008) and OLIVEIRA et al. (2007) detected STEC isolated from buffalos carrying stx in association with enterohemolysin and saa. The Hemolysin is produced by several pathogenic types of E. coli, which cause intestinal infections, especially NTEC, ETEC, and STEC strains. There is evidence of association of Shiga toxins and hemolysin production, indicating a possible role of hemolysin in bacterial virulence (SCHMIDT et al., 1995; MAINIL 2013). Our results indicated that STEC isolated from buffalos carry $s a a$, while EHEC harbor the enterohemolysin gene, eh $x A$, together with stx and eae genes.

Few studies on NTEC isolated from buffalo calves have been conducted. In our study, NTEC was detected at high frequency, in both diarrheic and non-diarrheic animals. Other studies also reported high incidence of NTEC (GALIERO et al., 2005; BORRIELLO et al., 2012) in relation to other pathovars. These results indicated that NTEC is a potential pathogenic pathovar for water buffalos.

The B1 was the most common phylogroup detected, and phylogroup $\mathrm{C}$ was associated with the presence of diarrhea. Our results are in accordance with those of others, demonstrating a high frequency of B1 E. coli strains in herbivorous animals (HIGGINS et al., 2007; BALDY-CHUDZIK; MACKIEWICZ; STOSIK, 2008; TENAILLON et al., 2010). CLERMONT et al. (2011) showed that intra-intestinal infections are caused mostly by A/ B1/E, while phylogroup C, a phylogroup closely related to phylogroup B1, included extra-intestinal and intestinal pathogenic E. coli. Our results demonstrated that $\mathrm{B} 1$ is the main $E$. coli phylogroup isolated from water buffalo calves, followed by phylogroup $\mathrm{E}$, and that phylogroup $\mathrm{C}$ is an intestinal pathogenic $E$. coli in water buffalo.

Using CA, the total variance explained by the analysis was $94.55 \%$, allowing the analysis to be used to study the relationship between $E$. coli pathovars and phylogroups. The analysis indicated that NTEC from water buffalo calves are close related to phylogroup B2 and, to a lesser extent, phylogroup D. NTEC (CNF2 positive strains) are able to cause diarrhea and invade the blood stream, causing bacteremia and septicemia in colostrum deprived newborn calves (VAN BOST; ROELS; MAINIL, 2001), and its importance in causing diarrhea in calves has increased over the years (KOLENDA; BURDUKIEWICZ; SCHIERACK, 2015). Extraintestinal E. coli (ExPEC) strains are clustered mostly in groups B2 and D (ESCOBARPÁRAMO et al., 2004). E. coli strains isolated from septicemic human patients belong mainly to groups B2 and D (ČUROVÁ et al., 2014), and CNF1 strains of phylogroup B2 are associated with diarrhea and mortality in puppies (TURCHETTO et al., 2015).

EPEC and EAEC isolated from water buffalo calves are mainly B1, and EHEC is mostly represented by phylogroup A. These findings are similar to results identified in other studies (BALDYCHUDZIK; MACKIEWICZ; STOSIK, 2008; TRAMUTA; ROBINO; NEBBIA, 2008). The ETEC is mainly phylogroup F. Studies showed no particular phylogenetic clustering of ETEC strains and toxinproducing and/or entero-invasive pathovars, such as ETEC and EHEC, which are usually reported in groups A, B1, C, or E (ESCOBAR-PÁRAMO et al., 2004). Our results involving ETEC are difficult to compare, since only two isolates of ETEC were detected, and both were negative for the toxin STa. 


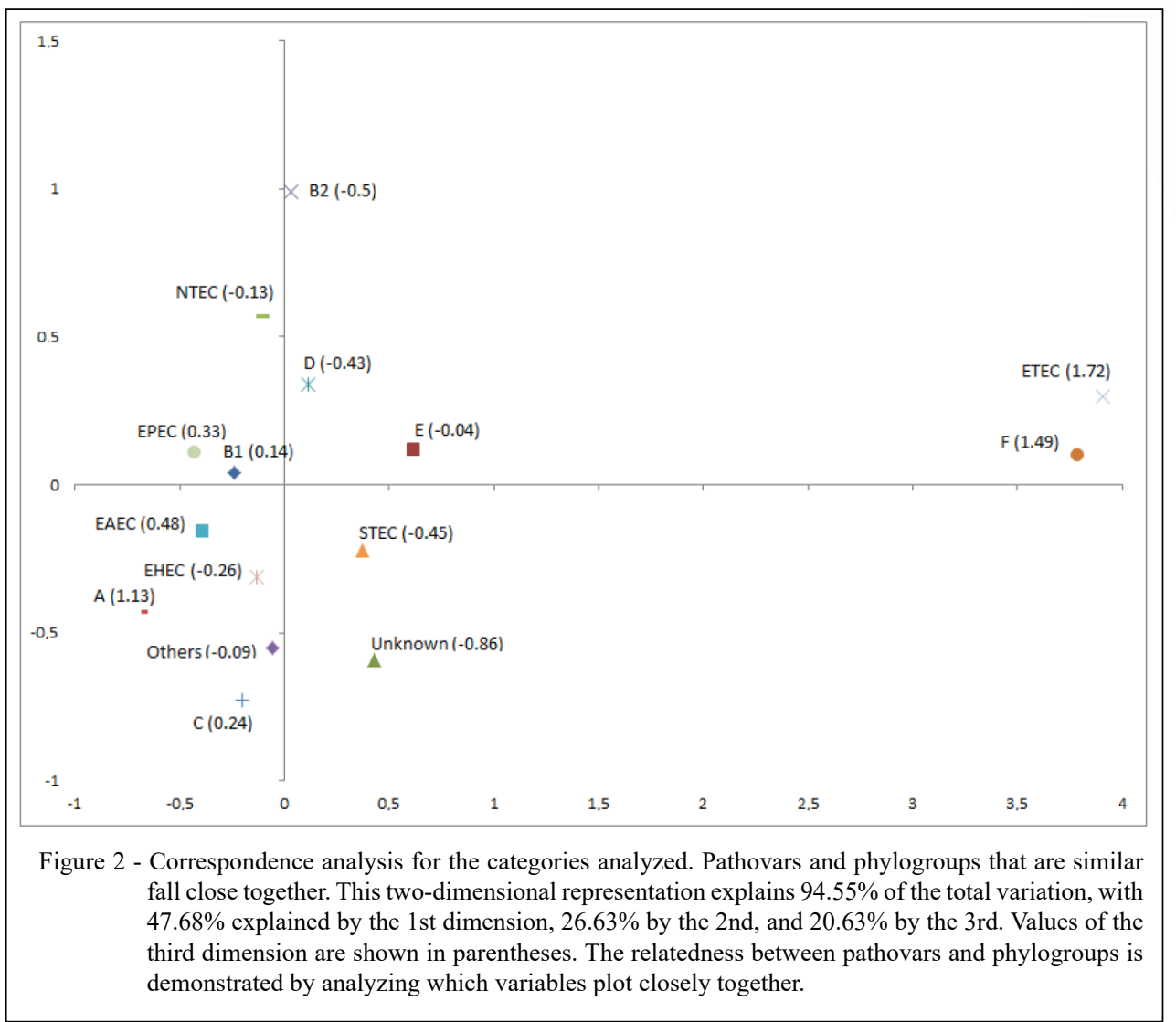

The detection of "unknown" phylogroup $E$. coli strains is not an unexpected result, since studies of $E$. coli phylogroups in water buffalo are rare. According to CLERMONT et al. (2013), E. coli strains that cannot be assigned to a phylogroup can occur due to the extremely rare occurrence of the phylogroup, the result of large-scale recombination involving two different phylogroups, or highly variable genome content of $E$. coli driven by gain and loss of genes.

The current study is important to advance our understanding of the epidemiology of pathogenic E. coli in water buffalos and the importance of diarrhea in these young animals, results that will likely have an impact on future control and prophylactic measures.

\section{CONCLUSION}

Pathovars EAEC (EAST- $\left.1^{+}\right)$and, to a lesser extent, NTEC $\left(\mathrm{CNF}^{+}\right)$and STEC, seem to be important agents of diarrhea. In contrast, pathovars ETEC $\left(\mathrm{F5}^{+}\right)$and EPEC are not as important as the other pathovars. The Phylogroup B1 predominates in pathogenic $E$. coli isolated from water buffalo, and phylogroup $C$ constitutes an enteric pathogenic $E$. coli in water buffalo calves. Identification of virulence factors, and performing microbial phylogenetic analyses, are useful molecular epidemiological tools when studying the occurrence of pathogenic E. coli and provided additional knowledge in understanding the pathogenesis of E. coli strains and their relationships with commensalism, host, and disease.

\section{ACKNOWLEDGEMENTS}

MBH, APL thanked CNPQ (Conselho Nacional de Desenvolvimento Científico e Tecnológico) for the fellowship. FMC, JMSM, CSFO and CHSO thanked CAPES (Coordenação de Aperfeiçoamento de Pessoal de Nível Superior) for the scholarship. This study was financed in part by CAPES, Brasil - Finance Code 001 and by CNPq (448357/2014-3).

\section{ETHICAL STANDARDS}

All procedures and animal handling followed ethical principles in animal experimentation, adopted by the Ethics 
Committee in Animal Experimentation of Universidade Federal de Minas Gerais (UFMG)/Comissão de Ética no Uso de Animais (CEUA), under Protocol n 133/2012.

\section{DECLARATION OF CONFLICT OF INTERESTS}

The authors declare no conflict of interest. The founding sponsors had no role in the design of the study; in the collection, analyses, or interpretation of data; in the writing of the manuscript, and in the decision to publish the results.

\section{AUTHORS' CONTRIBUTIONS}

All authors contributed equally for the conception and writing of the manuscript. All authors critically revised the manuscript and approved of the final version.

\section{REFERENCES}

ANDRADE, G. I. et al. Identification of virulence factors by multiplex PCR in Escherichia coli isolated from calves in Minas Gerais, Brazil. Tropical Animal Health and Production, v.44, n.7, p.1783-1790, 2012. Available from: <http://www.ncbi.nlm. nih.gov/pubmed/22476791>. Accessed: Nov. 20, 2013. doi: 10.1007/s11250-012-0139-8.

BALDY-CHUDZIK, K. et al. Phylogenetic background, virulence gene profiles, and genomic diversity in commensal Escherichia coli isolated from ten mammal species living in one zoo. Veterinary Microbiology, v.131, n.1-2, p.173-184, 2008. Available from: $<$ https://www.ncbi.nlm.nih.gov/pubmed/18423907>. Accessed: Nov. 20, 2013. doi: 10.1016/j.vetmic.2008.02.019.

BERALDO, L. G. et al. Detection of Shiga toxigenic (STEC) and enteropathogenic (EPEC) Escherichia coli in dairy buffalo. Veterinary Microbiology, v.170, n.1-2, p.162166, 2014. Available from: <https://www.ncbi.nlm.nih.gov/ pubmed/24560591>. Accessed: Nov. 25, 2015. doi: 10.1016/j. vetmic.2014.01.023.

BLANCO, M. et al. Polymerase chain reaction for detection Escherichia coli strains producing cytotoxic necrotizing factor type 1 and type 2 (CNF1 and CNF2 ). Journal of Microbiological Methods, v.26, p.95-101, 1996. Available from: <https://ac.els-cdn. com/0167701296009001/1-s2.0-0167701296009001-main.pdf? tid $=$ ca154fac-3579-4e95-b202-8ca25c315a70\&acdnat $=1543246615$ a8ff6b54fd0eb02316aaf62393ed6439>. Accessed: Nov. 20, 2013. doi: 10.1016/0167-7012(96)00900-1.

BORRIELLO, G. et al. Characterization of enterotoxigenic E. coli (ETEC), Shiga-toxin producing E. coli (STEC) and necrotoxigenic E. coli (NTEC) isolated from diarrhoeic Mediterranean water buffalo calves (Bubalus bubalis). Research in Veterinary Science, v.93, n.1, p.18-22, 2012 Available from: <http://linkinghub.elsevier.com/retrieve/pii/ S0034528811001834>. Accessed: Nov. 20, 2013. doi: 10.1016/j. rvsc.2011.05.009.

CLERMONT, O. et al. Animal and human pathogenic Escherichia coli strains share common genetic backgrounds. Infection, Genetics and Evolution : Journal of Molecular Epidemiology and Evolutionary Genetics in Infectious Diseases, v.11, n.3, p.654-662, 2011. Available from: <http://www.ncbi.nlm.nih.gov/ pubmed/21324381>. Accessed: Nov. 20, 2013. doi: 10.1016/j. meegid.2011.02.005.

CLERMONT, O. et al. The Clermont Escherichia coli phylo-typing method revisited: improvement of specificity and detection of new phylo-groups. Environmental Microbiology Reports, v.5, n.1, p.58-65, 2013. Available from: <http://www.ncbi.nlm.nih.gov/ pubmed/23757131>. Accessed: Nov. 11, 2013. doi: 10.1111/17582229.12019 .

CLERMONT, O. et al. Rapid and simple determination of the Escherichia coli phylogenetic group. Applied and Environmental Microbiology, v.66, n.10, p.4555-4558, 2000. Available from: <http://www.pubmedcentral.nih.gov/ articlerender.fcgi?artid $=92342 \&$ tool $=$ pmcentrez $\&$ rendertype $=a b$ stract>. Accessed: Nov. 11, 2013

CLERMONT, O. et al. Guide to the various phylogenetic classification schemes for Escherichia coli and the correspondence among schemes. Microbiology, v.161, p.980-988 2015. Available from: <http://mic.sgmjournals.org/cgi/doi/10.1099/ mic.0.000063>. Accessed: Nov. 11, 2015. doi: 10.1099/ mic.0.000063.

COURA, F. M. et al. Longitudinal study of Salmonella spp., diarrheagenic Escherichia coli, Rotavirus, and Coronavirus isolated from healthy and diarrheic calves in a Brazilian dairy herd. Tropical Animal Health and Production, v.47, n.1, p.3-11, 2015a. Available from: <http://link.springer.com/10.1007/s11250014-0675-5>. Accessed: Nov. 11, 2015. doi: 10.1007/s11250-0140675-5.

COURA, F. M. et al. Phylogenetic group determination of Escherichia coli isolated from animals samples. The Scientific World, v.2015, p.1-4, 2015b. Available from: <https://www. hindawi.com/journals/tswj/2015/258424/>. Accessed: Nov. 11, 2015. doi: $10.1155 / 2015 / 258424$.

CROXEN, M. et al. Molecular mechanisms of Escherichia coli pathogenicity. Nature Reviews Microbiology, v.8, n.1, p.26-38, 2010. Available from: <http://www.ncbi.nlm.nih.gov/ pubmed/19966814>. Accessed: Nov. 13, 2013. doi: 10.1038/ nrmicro2265.

ČUROVÁ, K. et al. Toxins of extraintestinal Escherichia coli isolated from blood culture. Clinical Microbiology: Open Access, v.3, n.5, p.5-8, 2014. Available from: <http://esciencecentral.org/ journals/toxins-of-extraintestinal-escherichia-coli-isolated-fromblood-culture-2327-5073.1000171.php?aid=31073>. Accessed: Nov. 13, 2015. doi: 10.4172/2327-5073.1000171.

DOYLE, M. P. Escherichia coli O157:H7 and its significance in foods. International Journal of Food Microbiology, v.12, n.4, p.289-301, 1991. Available from: <https://www.ncbi.nlm.nih.gov/ pubmed/1854598>. Accessed: Nov. 13, 2013. doi: 10.1016/01681605(91)90143-D.

ESCOBAR-PÁRAMO, P. et al. A specific genetic background is required for acquisition and expression of virulence factors in Escherichia coli. Molecular Biology and Evolution, v.21, n.6, p.1085-1094, 2004. Available from: <https://www.ncbi.nlm.nih. gov/pubmed/15014151>. Accessed: Nov. 13, 2013. doi: 10.1093/ molbev/msh118.

FAGIOLO, A. et al. Buffalo pathologies. In: BORGHESE, A. (Ed.), Buffalo Production and Research. Rome, FAO Regional 
Office for Europe Inter-Regional Cooperative Research Network on Buffalo. 2005. Chap. XIII, p.249-296.

FRANCK, S. M. et al. Multiplex PCR for enterotoxigenic, attaching and effacing, and Shiga toxin-producing Escherichia coli strains from calves. Journal of Clinical Microbiology, v.36, n.6, p.1795-1797, 1998. Available from: <http://www.pubmedcentral. nih.gov/articlerender.fcgi?artid=104926\&tool=pmcentrez\&render type $=$ abstract $>$. Accessed: Nov. 11, 2013.

GALIERO, G. et al. Isolation of verocytotoxin-producing Escherichia coli $\mathrm{O} 157$ from water buffaloes (Bubalus bubalis) in southern Italy. The Veterinary Record, v.156, n.12, p.382383, 2005. Available from: <http://www.ncbi.nlm.nih.gov/ pubmed/15816184>. Accessed: Nov. 20, 2013. doi: 10.1136/ vr.156.12.382.

GORDON, D. M. et al. Assigning Escherichia coli strains to phylogenetic groups: multi-locus sequence typing versus the PCR triplex method. Environmental Microbiology, v.10, n.10, p.2484-2496, 2008. Available from: <http://www.ncbi.nlm. nih.gov/pubmed/18518895>. Accessed: Nov. 20, 2013. doi: 10.1111/j.1462-2920.2008.01669.x.

GREENACRE, M.; BLASIUS, J. Multiple correspondence analysis and related methods: CRC Press, 2006. 608p.

HAIR, J.F. et al. Multivariate data analysis. New York :Bookman, 2009. 149-220p.

HIGGINS, J. et al. Genotyping of Escherichia coli from environmental and animal samples. Journal of Microbiological Methods, v.70, n.2, p.227-235, 2007. Available from: <http:// www.ncbi.nlm.nih.gov/pubmed/17521755>. Accessed: Nov. 20, 2013. doi: 10.1016/j.mimet.2007.04.009.

JENKINS, C. et al. Distribution of the saa gene in strains of Shiga toxin-producing Escherichia coli of human and bovine origins. Journal of Clinical Microbiology, v.41, n.4, p. 1775-1778, 2003. Available from: $<$ http://www.pubmedcentral.nih.gov/articlerender. fcgi artid $=153935 \&$ tool $=$ pmcentrez $\&$ rendertype $=$ abstract $>$. Accessed: Nov. 20, 2013. doi: 10.1128/JCM.41.4.1775-1778.2003.

KOLENDA, R. et al. A systematic review and meta-analysis of the epidemiology of pathogenic Escherichia coli of calves and the role of calves as reservoirs for human pathogenic E. coli. Frontiers in Cellular and Infection Microbiology, v.5, 2015. Available from: $<$ http://journal.frontiersin.org/article/10.3389/fcimb.2015.00023>. Accessed: Nov. 20, 2015. doi: 10.3389/fcimb.2015.00023.

MAHANTI, A. et al. Isolation, molecular characterization and antibiotic resistance of Shiga Toxin-Producing Escherichia coli (STEC) from buffalo in India. Letters in Applied Microbiology, v.56, n.4, p.291-298, 2013. Available from: <http://www.ncbi. nlm.nih.gov/pubmed/23350641>. Accessed: Nov. 8, 2015. doi: 10.1111/lam.12048.

MAINIL, J. Escherichia coli virulence factors. Veterinary Immunology and Immunopathology, v.152, n.1-2, p.212, 2013. Available from: <http://www.ncbi.nlm.nih.gov/ pubmed/23083938>. Accessed: Nov. 20, 2015. doi: 10.1016/j. vetimm.2012.09.032.

MARTIN, A.; BEUTIN, L. Characteristics of Shiga toxinproducing Escherichia coli from meat and milk products of different origins and association with food producing animals as main contamination sources. International Journal of Food Microbiology, v.146, n.1, p.99-104, 2011. Available from: <http:// dx.doi.org/10.1016/j.ijfoodmicro.2011.01.041>. Accessed: Nov. 20, 2013. doi: 10.1016/j.ijfoodmicro.2011.01.041.

MCDANIELS, A. E. et al. Confirmational identification of Escherichia coli, a comparison of genotypic and phenotypic assays for glutamate decarboxylase and B-D-glucorinase. Applied and Environmental Microbiology, v.62, n.9, p.33503354, 1996. Available from: <https://www.ncbi.nlm.nih.gov/ pubmed/8795225>. Accessed: Nov. 19, 2013.

NAGY, B.; FEKETE, P. Z. Enterotoxigenic Escherichia coli in veterinary medicine. International Journal of Medical Microbiology : IJMM, v.295, n.6-7, p.443-54, 2005. Available from: <http://www.ncbi.nlm.nih.gov/pubmed/16238018>. Accessed: Nov. 19, 2013. doi: 10.1016/j.ijmm.2005.07.003.

NGUYEN, T. D. et al. Virulence factors in Escherichia coli isolated from calves with diarrhea in Vietnam. Journal of Veterinary Science, v.12, n.2, p.159-164, 2011. Available from: <https:// www.ncbi.nlm.nih.gov/pubmed/21586875>. Accessed: Nov. 19, 2013. doi: $10.4142 /$ jvs.2011.12.2.159.

OK, M. et al. The studies on the aetiology of diarrhoea in neonatal calves and determination of virulence gene markers of Escherichia coli strains by multiplex PCR. Zoonoses and Public Health, v.56, n.2, p.94-101, 2009. Available from: <http://www.ncbi. nlm.nih.gov/pubmed/18771515>. Accessed: Nov. 20, 2013. doi: 10.1111/j.1863-2378.2008.01156.x.

OLIVEIRA, M. G. et al. Water buffaloes (Bubalus bubalis) identified as an important reservoir of Shiga toxin-producing Escherichia coli in Brazil. Applied and Environmental Microbiology, v.73, n.18, p.5945-5948, 2007. Available from: $<$ http://www.pubmedcentral.nih.gov/articlerender.fcgi?artid=207 4925\&tool $=$ pmcentrez\&rendertype $=$ abstract $>$. Accessed: Nov. 7, 2013. doi: 10.1128/AEM.00929-07.

PATON, A. W. et al. Characterization of Saa, a novel auto agglutinating adhesin produced by locus of enterocyte effacementnegative Shiga-toxigenic Escherichia coli strains that are virulent for humans. Infection and Immunity, v.69, n.11, p.6999-7009, 2001. Available from: <http://www.pubmedcentral.nih.gov/articlerender. fcgi . artid $=100080 \&$ tool $=$ pmcentrez $\&$ rendertype $=$ abstract $>$. Accessed: Nov. 20, 2013. doi: 10.1128/IAI.69.11.6999-7009.2001.

PITCHER, D. et al. Rapid extraction of bacterial genomic DNA with guanidium thiocyanate. Letters in Applied Microbiology, v.8, p.151-156, 1989. Available from: $<$ https://onlinelibrary.wiley. com/doi/abs/10.1111/j.1472-765X.1989.tb00262.x>. Accessed: Nov. 20, 2013. doi: 10.1111/j.1472-765X.1989.tb00262.x.

SCHMIDT, H. et al. Molecular analysis of the plasmidencoded hemolysin of Escherichia coli O157:H7 strain EDL 933. Infection and Immunity, v.63, n.3, p.1055-1061, 1995. Available from: <http://www.pubmedcentral.nih.gov/ articlerender.fcgi? artid $=173109 \&$ tool $=$ pmcentrez\&rendertype $=$ abstract>. Accessed: nov. 20, 2013.

STATACORP. Stata Statistical Software: Release 12. College Station, TX, 2011.

TENAILLON, O. et al. The population genetics of commensal Escherichia coli. Nature Reviews Microbiology, v.8, n.3, p.207-217, 2010. Available from: <http://www.ncbi.nlm.nih.gov/ 
pubmed/20157339>. Accessed: Nov. 13, 2013. doi: 10.1038/ nrmicro2298.

TRAMUTA, C. et al. Phylogenetic background of attaching and effacing Escherichia coli isolates from animals. Veterinary Research Communications, v.32, n.6, p.433-437, 2008. Available from: $<$ https://www.ncbi.nlm.nih.gov/pubmed/18509740>. Accessed: Nov. 13, 2013. doi: 10.1007/s11259-008-9042-1.

TURCHETTO, S. et al. Phenotypic features and phylogenetic background of extraintestinal hemolytic Escherichia coli responsible of mortality in puppies. Veterinary Microbiology, v.179, n.1-2, p.126-130, 2015. Available from: $<$ http://dx.doi.org/10.1016/j.vetmic.2015.03.004>. Accessed: Nov. 13, 2015. doi: 10.1016/j.vetmic.2015.03.004.

VAN BOST, S. et al. Necrotoxigenic Escherichia coli type-2 invade and cause diarrhoea during experimental infection in colostrum-restricted newborn calves. Veterinary Microbiology, v.81, n.4, p.315-329, 2001. Available from: <https://www.ncbi. nlm.nih.gov/pubmed/11390113>. Accessed: Nov. 13, 2013. doi: 10.1016/S0378-1135(01)00360-1.
VEILLEUX, S.; DUBREUIL, J. D. Presence of Escherichia coli carrying the EAST1 toxin gene in farm animals. Veterinary Research, v.37, p.3-13, 2006. Available from: <https://www.ncbi. nlm.nih.gov/pubmed/16336921>. Accessed: Nov. 13, 2013. doi: 10.1051/vetres:2005045.

VU-KHAC, H.; CORNICK, N. A. Prevalence and genetic profiles of Shiga toxin-producing Escherichia coli strains isolated from buffaloes, cattle, and goats in central Vietnam. Veterinary Microbiology, v.126, n.4, p.356-363, 2008. Available from: $<$ http://www.ncbi.nlm.nih.gov/pubmed/17716835>. Accessed: Nov. 20, 2013. doi: 10.1016/j.vetmic.2007.07.023.

YAMAMOTO, T.; NAKAZAWA, M. Detection and sequences of the enteroaggregative Escherichia coli heat-stable enterotoxin 1 gene in enterotoxigenic $E$. coli strains isolated from piglets and calves with diarrhea. Journal of Clinical Microbiology, v.35, n.1, p.223-227, 1997. Available from: $<$ http://www.pubmedcentral.nih.gov/articlerender.fcgi?artid $=229543 \&$ tool $=$ pmcentrez $\&$ rendertype $=$ abstract $>$. Accessed: Nov. 20, 2013. 